\title{
The Role of Brazilian Intelligence in the Geopolitics of Grandeza (1964-2002)*
}

\author{
Gisela da Silva Guevara (Portugal)**
}

\begin{abstract}
Far from what most scholars have assumed, under the authoritarian regime (1964-1985) Brazil did not limit itself to importing anticommunist concepts from the United States, but it developed a conceptualization of its own aimed at transforming the country into a regional hegemon. The author's starting assumption is that little attention has been paid to the role of Brazilian intelligence in the aspirations of the leaders of the country since the putsch of 1964, who followed the scope of achieving regional hegemony. Moreover, this article shall show that this aim has historical continuity from the authoritarian regime through democratic Brazil given the fact that intelligence was still employed to support the country's aspirations of greatness (Grandeza) under Collor de Mello (1990-1992) and Fernando Henrique Cardoso (1995-2002).
\end{abstract}

\section{Keywords}

International Relations; Geopolitics; Regional Hegemony; Security; Intelligence; Brazil.

Reception Date: October 2018 - Approval Date: March 2019

\section{How to Cite this Article}

Guevara, Gisela da Silva. (2019). The Role of Brazilian Intelligence in the Geopolitics of Grandeza (1964-2002). Estudios Políticos (Universidad de Antioquia), 55, pp. 140-162. http://doi.org/10.17533/udea.espo.n55a07

\footnotetext{
* Article originally derived from a postgraduate thesis submitted at the University Brunel, London, which was later developed within the framework of a new theoretical approach in the field of Latin American geopolitics.

** BA in History. MA in Intelligence and Security Studies. PhD in Political Science and International Relations. Professor and researcher at the Faculty of Finances, Government and International Relations, Externado de Colombia University. Email: gisela.silvaguevara@gmail.com - Orcid: https:// orcid.org/0000-0003-3905-4762
} 


\section{El papel de la inteligencia brasileña en la geopolítica de Grandeza (1964-2002)}

\section{Resumen}

Lejos de lo que la mayoría de los estudiosos han asumido, bajo el régimen autoritario (1964-1985) Brasil no se limitó a la importación de conceptos anticomunistas de Estados Unidos, sino que desarrolló una conceptualización propia que buscaba transformar al país en una potencia hegemónica regional. El punto de partida de este artículo es que se ha prestado poca atención al papel de la inteligencia brasileña en las aspiraciones de los líderes del país desde el golpe de Estado de 1964 en aras de alcanzar la hegemonía regional. Además, este artículo demuestra que este objetivo tiene una continuidad histórica entre el régimen autoritario y el Brasil democrático, dado que la inteligencia todavía se ha empleado para apoyar las aspiraciones de grandeza del país - Grandeza - bajo los mandatos de Fernando Collor de Mello (1990-1992) y Fernando Henrique Cardoso (19952002).

\section{Palabras clave}

Relaciones Internacionales; Geopolítica; Hegemonía Regional; Seguridad; Inteligencia; Brasil. 


\section{Introduction}

Economic power, number of inhabitants, access to technology and military power are decisive requirements for a country to become a rising power (NIC, 2004, p. 9). ${ }^{1}$ Nonetheless, intelligence is also a crucial tool for nations with aspirations to become regional hegemons. According to Marco Cepik (2002, p. 264), «information superiority» allows a more efficient management of human and material resources, increases the survivability of military forces and contributes to better performing the functions of command during a war. Furthermore, Cepik (2007, p. 150) observes that «intelligence services are an essential part —along with the military, police, and diplomats - of the bureaucratic apparatus of any state with minimal intentions of having autonomy ${ }^{2}$ in the international system.» For his part, Michael Herman (2003) points out that intelligence is «a significant part of the modern state and a factor in government's success and failure. [...] It constitutes its own particular kind of state power: intelligence power.» (p. 2).

According to Cepik (2002), intelligence services cannot be defined as hard power because they fulfill informational functions but they can [142] be used for coercive purposes. Nonetheless, Intelligence has often been viewed as a tool of hard power. A publication of the US Army describes the intelligence warfighting function as «the product resulting from the collection, processing, integration, evaluation, analysis, and interpretation of available information concerning foreign nations, hostile or potentially hostile forces or elements, or areas of actual or potential operations.» It follows: «The Army generates intelligence through the intelligence warfighting function.» (Headquarters. Department of the US Army, 2010). From the author's perspective, the current case study would be better investigated if it is assumed that Brazilian intelligence services were a

\footnotetext{
${ }^{1}$ See for instance, the report of National Intelligence Council on China and India: «A combination of sustained high economic growth, expanding military capabilities, and large populations will be at the root of the expected rapid rise in economic and political power for both [China and India] countries.» (NIC, 2004).

${ }^{2}$ According to Tullo Vigevani and Gabriel Cepaluni (2009, p. 5), autonomy can be generally defined as «the condition allowing states to formulate and implement foreign policies independently of constraints imposed by more powerful states. This term lies within a continuum whose extremities are total dependence (or alignment) and full autonomy.»
} 
crucial tool of smart power ${ }^{3}$ strategies to consolidate the country's regional ambitions between 1964 and 2002. ${ }^{4}$

In order to conduct the present research it is necessary to take into account various notions of what defines regional powers ideational projects and their strategies, particularly those of Brazil. As Andrew Hurrell (2010, p. 16) states, «ideas and interests of regional powers can rarely be understood solely within a domestic or regional context. Regional powers do not exist as closed-off entities.» In turn, Kurt Weyland (2016, pp. 145-146) highlights the «means-ends dilemma that constraints rising middle powers: if they want to propel their ascendance, they must foreswear antagonism against established powers and forgo aggression against the weaker neighbors.» Also, Sean Burges (2009) argues that there is an ideational dimension of the Brazilian leadership after the Cold War that aimed at articulating South America «as a distinct geoeconomic and geopolitical space.» (p. 14).

Daniel Flemes (2010, p. 100) states that «for a long time Brazil has been regarded as a passive regional power in a South America marked by self-isolation.» Since the Cardoso administration, mainly during his second period, Brazil focused decisively on South America, which meant, inter alia, employing regional strategies in order to consolidate Brazil's regional leadership; for example, mediating regional territorial conflicts. As Matias Spektor (2010, p. 192) observes, «Brazil's regional activism [...] can be traced back to the 1980s, gaining momentum in the late 1990s and 2000s.» In turn, Burges (2009, p. 27) highlights that under the Figueiredo presidency, during the authoritarian regime, there was a «resurgence of regional integration policies in the Southern Cone.» Referring mainly to Brazil, India and South Africa in the $21^{\text {st }}$ century, Philip Nel \& Matthew Stephen (2010, p. 71) stress that «in their regions» regional powers «rely on a preponderance of material and ideational resources and institutional capacities to project their interests and values beyond their immediate borders and provide some cohesion to the region by delivering one or more public goods.»

\footnotetext{
${ }^{3}$ According to Joseph Nye (2004) smart power combines soft and hard power.

${ }^{4}$ For a conceptualization of Brazil's smart power strategies between 2003 and 2014 see Gisela da Silva Guevara (2018).
} 
Since Brazil had not mainly used military actions in South America during the $20^{\text {th }}$ century, ${ }^{5}$ some scholars highlight that the country's strategies aimed at consolidating a «South American region» under Brasilia's leadership were pursued by means of economic cooperation with its neighbors. For example, Burges (2009) stresses Brasilia's strong economic presence since the 1970s in Bolivia and Paraguay, whereas Weyland (2016, pp. 145-146) underscores that «Brazil's determination to augment its national power [...] requires economic cooperation to boost its development and thereby strengthen its resource base for projecting international influence.»

This paper argues that in order to better explain Brazil's strategies to advance an autonomous project of «Brasil potencia» since 1964, it is important to take into account actions pursued by Brazilian intelligence services in South America backed by the ideational project of Brazil's role in the region as guarantor for security and development. Since the nation has been peaceful and has avoided involvement in interstate armed conflicts, one might mistakenly claim that intelligence has not played a significant role in this country. But this premise does not resist a closer review of sources. In fact, Brazil has employed sophisticated intelligence since the 1960s to influence its neighbors broadly.

The author's starting hypothesis is that little attention has been paid to the role of Brazilian intelligence in the aspirations of the leaders of the country since the putsch of 1964, following the scope of achieving regional hegemony. Moreover, this article shall show that there is a historical continuity from the authoritarian regime through democratic Brazil given the fact that intelligence was still employed to support the country's aspirations of greatness (Grandeza) under Collor de Mello and Fernando Henrique Cardoso.

The various approaches to hegemony in international relations make it difficult to define precisely the role of Brazil in regional affairs. According to Dirk Nabers (2010, p. 69), «in a nutshell, hegemony means nothing more than the discursive struggle between political actors over the assertion that their particular representations of the world have a universal significance.» Burges (2009, p. 10) introduced the notion of a «consensual hegemony»

\footnotetext{
${ }^{5}$ Although, out of South America, Brazil was one of the invading countries during the intervention led by the United States in the Dominican Republic in 1965.
} 
that is «not about the framing of an explicit power relationship [...]. Rather it focuses on the construction of a project, in the Brazilian case, on various regional initiatives in South America.» Tracing back the Brazilian project of a South American regionalism, Burges argues that this project had less successful outcomes from Rio Branco to President Kubitschek.

Brazil has tried, in most cases successfully, to influence its neighbors not only by financial and economic means but also by cooperating with neighboring countries in intelligence issues. From 1964 through 1985, this cooperation aimed not only at creating regional security based on the conception that communist subversion was the main obstacle to development, but also at achieving regional hegemony.

Since 1990 until 2002, when Brazil began to consolidate its democracy, intelligence was used to challenge a perceived US threat from the North against Brazilian sovereignty, particularly in the Amazon. Furthermore, democratic Brazil established a monitoring system over the Amazon, SIVAM, ${ }^{6}$ aimed not only at facing presumed threats from developed countries, but also at consolidating regional hegemony.

\section{Golbery do Couto e Silva: The State and the Strategy of Fighting Subversion}

When Minister of External Relations Oswaldo Aranha urged for an alliance with the United States and for to Brazil to participate in World War II in 1943, one of the advantages he had in mind for his country was «a better position in world politics» after the end of the conflict (MacCann, 1995). Nonetheless, the aspiration for a better position in the post-war world order was soon confronted by the awareness that, despite Brazil's participation in World War II, no substantial advantages would be obtained. ${ }^{7}$ The failure of the South American nation to accomplish its dream of holding a permanent seat on the UN Security Council would have substantial implications for the foreign policy pursued by Brazil toward the United States during a great part of the Cold War.

\footnotetext{
${ }^{6}$ SIVAM, the Amazon Surveillance System, consists of an advanced electronic system in the Amazon basin to monitor illegal activities such as drug trafficking and to control natural resources.

${ }^{7}$ For more on the Brazilian expeditionary force (FEB) sent to fight in WWII, see Frank MacCann (1995).
} 
In fact, during the Cold War Brazil conducted regional and hemispheric strategies, combining autonomy and acquiescence dynamics, aiming at less asymmetric relations with the United States. ${ }^{8}$ Moreover, multilateral initiatives such as the Contadora Group sought to negotiate a settlement in Central America aimed at restraining US influence (Weyland, 2016). The same could be said regarding the Amazon Cooperation Treaty signed in 1978.

An imposed bipolar order gave the Brazilian leaders a welcome opportunity to enhance the position of the nation as the protector of the values of Western Christian civilization. Thus, authoritarian Brazil positioned itself in Latin America as an important ally of the United States. But on the other hand, decision makers could not forget the betrayed aspirations of Brazil vis-à-vis Washington in the 1950s.

In 1964, President João Goulart's foreign policy regarding the United States was deemed too independent, raising serious concerns on the part of Washington and Brazilian anti-leftist social sectors. Nonetheless, when a military coup overthrew him in 1964, the autonomous project regarding «Brasil potencia» was not forgotten. In fact, it was pursued under the authoritarian regime.

The military officers that instigated the coup shared the belief that national security, stability and development were crucial components of greatness (Grandeza). ${ }^{9}$ Among the leading figures of the group responsible for the putsch that led Goulart to step down were Golbery do Couto e Silva and Carlos de Meira Mattos. The former had received advanced military training in 1944 at Fort Leavenworth, Kansas, and had served as an intelligence officer with the Força Expedicionária Brasileira (FEB), the Brazilian expeditionary force sent to fight in World War II (Rose, 2005). Later, he created in the 60s the Serviço Nacional de Informações (SNI), the national intelligence agency of Brazil.

The General became the first head of the organization. The SNI was to supervise and to coordinate intelligence and counter-intelligence activities in the country in the realm of national security (Antunes, 2002). Among its most

\footnotetext{
${ }^{8}$ See also regarding this Guevara \& Ardila (2018) based on the approaches of Russell \& Tokatlian's on relational autonomy.

${ }^{9}$ Grandeza is briefly defined by Jack Child (1979, p. 90) as «The search for great power status.»
} 
important tasks were to advise the President on security issues, to create a national system of information, to gather and evaluate intelligence information, and to coordinate and to plan the activities of the General Secretary of the National Security Council (Stepan, 1988).

Golbery do Couto e Silva believed that the centralization of power was necessary to enhance security in Brazil from a Hobbesian perspective, although he cautioned against any abuses that could derive from a misinterpretation of this postulate (Guevara, 2014, 4-7 August). The viewpoint of do Couto e Silva was that, given a context in which communists had chosen a subtle way to infiltrate Western societies, the application of «preventive and, if necessary, repressive measures» (E Silva, 1967, p. 22) was a blunt need. According to him, South America had to make every possible effort to avoid falling into the arms of Communism. Nonetheless, the General pointed out that the securityfreedom dilemma was difficult to solve.

According to Pedro Rivas Nieto (2008) the national security doctrine, which was conceptualized in the United States and expanded to Latin America, had as main concern the fight against Communism using any means necessary. It was assumed that if the enemy was not destroyed, the survival of all the nation would be jeopardized. But Golbery do Couto e Silva's focus was not only on Brazil's loyalty to the United States in this fight. Rather, his main aim was that the struggle against Communism would enhance the position of the country in the hemispheric dynamics, leading it out of the periphery.

Within the context of the Cold War, the Cuban missile crisis, and increasing activities from guerrilla movements, the Brazilian military began to develop a national security doctrine with a counter-subversion emphasis. A new kind of warfare emerged, somewhat different from that of classical wars. In his Geopolítica do Brasil, do Couto e Silva mentioned his concerns over the variety of guerrilla warfare tactics and ideological communist diffusion strategies, using social tensions to attain communist objectives (E Silva, 1967, p. 137). According to what he saw as the main national security goals, the security strategy of Brazil had to consider aspects of internal and external geopolitical security as well, while jointly cooperating with underdeveloped nations and power centers of the Western world, in order to consolidate its position in global affairs. 
The General highlighted the significant role Brazil should play in the Western Hemisphere through its continental and global prestige, and its crucial geoestrategic position in the South Atlantic (E Silva, 1967). He also put a strong emphasis on the presumed ability of Brazilian decision makers to better understand the problems of the developing world.

It is also important to take into consideration do Couto e Silva's concept of the role of the state in the strategy for fighting subversion and Communism, because the argument of this article is based precisely on the idea that the Brazilian military developed an efficient security apparatus in which intelligence would be very significant, allowing the nation to play a much more proactive and independent role in the security strategy of the Western world than is commonly assumed.

The Brazilian authoritarian regime was supported in the 70s by an economic growth that reached $9.6 \%$ while developed countries such the United States were affected by the oil crisis (Gaspari, 2014). But President Geisel and some of his advisers had more ambitious objectives. They aimed to enhance the position of the country in the Atlantic by recognizing the independence of African countries such Angola, even against the will of the [148] United States.

Kissinger was sent by Washington to criticize Brasilia's stance in relation to former Portuguese colonies where socialist leaders such as Agostinho Neto seized power. Moreover, Brazilian intelligence services were collaborating with Portuguese General Spínola, preparing a possible coup in Portugal (Gaspari, 2014). Brazil's ambitions were going global, even against the interests of the United States. Nonetheless, the relationship between the SNI and President Geisel was stressful, since the government decided to recognize the Popular Republic of China, against the stance of senior officers of the SNI more aligned with an orthodox anticommunist ideology.

Priscilla Antunes (2002, p. 76) mentions that in Brazil «intelligence activities were identified with national security itself.» But it was the highly sophisticated professionalization of intelligence (Stepan, 1988) under the supervision of the military that led Brazilian intelligence agencies to play a key role in the national security apparatus. 
Repression and close surveillance of domestic «subversive» elements were common in Brazil (Stepan, 1988; Antunes, 2002). Thus, combating supposed subversives was an important component of the training and education of Brazilian intelligence officials. In this regard, it is worth noting that the final scope of intelligence activities, in line with the military ideology of the 1960s and 1970s, was to ensure that the vital Objetivos Nacionais Permanentes (permanent objectives of the nation) were achieved. ${ }^{10}$

More than subserviently helping US foreign policy goals against Communism, as argued by some authors, ${ }^{11}$ the Brazilian state was to enhance the removal of subversion foci according to national interests. Chaos derived from «red» subversion was considered to be a major obstacle to attain Grandeza. But when Carter came to power, in 1977, the priority given to human rights in the foreign policy of the United States (Rivas, 2008) had implications for the US-Brazil relations. Meanwhile, in the mid-70s an intense debate took place in the Geisel government on this issue and on how to answer allegations of human rights abuses in the context of rising concerns on the part of multilateral organisms, such as the United Nations (CNV, 2014).

In the 1970s US intelligence estimated that Brazilian armed forces considered it was their duty to guide the South American country to «its rightful place in the world,» viewing civilian politicians with distrust (Kraft \& Siekmeier, 2009, Doc. 146). It is undeniable that there were close ties between Brazilian and US intelligence, and that US military agencies and their training schools ${ }^{12}$ had a deep influence on the development of the Brazilian national security doctrine (MacSherry, 2009; Comblin, 1979). ${ }^{13}$ Nonetheless, the Brazilian military regime had ambitious goals that went well beyond a mere combat against subversion, following US anticommunist guidelines; it aspired to become a regional hegemon in Latin America. ${ }^{14}$

\footnotetext{
${ }^{10}$ On the ONP, Objetivos Nacionais Permanentes, national permanent objectives, see above Golbery do Couto e Silva (1967).

${ }^{11}$ For example, Alan Rouquié (2007, p. 341) emphasizes on Brazil's dependency on the United States, mentioning the «suivisme militant» of President Castelo Branco.

${ }^{12}$ With regard to the importance of the US Army School of the Americas for the training of the Latin American military see Carlston Fox (2001), who argues that «Throughout the USARSA's 54 years existence placed the United States in an influential position to achieve U.S. national interests by thwarting Communist insurgencies [...]» (p. 81).

${ }^{13}$ Comblin, a Belgian priest, saw the United States as the influence, par excellence, behind the entire development of the Brazilian security doctrine.

${ }^{14}$ The CIA and the Department of State saw Brazil's aims as «seeking to fill whatever vacuum the US leaves behind» (Kraft \& Siekmeier, 2009, Doc. 146).
} 


\section{Brazil and its Intelligence Apparatus: The Bid for Regional Influence}

After cooperating with the first and third world to remove the internal threat of subversion, the Brazilian national security doctrine's long-term scope under the military was to secure an important place for the country on the international stage. Thus, the idea that foreign security concepts were simply imported into the Brazilian national security doctrine fails to appreciate the Brazilian ambitions for regional and international leadership. For instance, Priscilla Antunes (2002, p. 78) sees the role of Brazilian intelligence officers merely as a tool of the United States to indoctrinate others in a process of ideology exportation in order to fight Communism. The idea of the importation of security concepts can also be seen in Diego Cardona (2004).

The author of this article disagrees with scholars who see these concepts merely as a copy of the US security conception. While the military regime was focused on the short-term goal of eliminating subversion, seen as a main obstacle to national development, it maintained the long-term vision of Brazil playing a vital role between the global North and South. Furthermore, it is important to note that Golbery do Couto e Silva (1967) stressed that the

[150] United States had to understand the legitimacy of Brazil's aspirations toward global power, stating: «We can also fulfill our "manifest destiny"» (p. 52). Moreover, the General argued that since «among our neighbors there is a growing opposition to the United States, which cannot be hidden,» Brazil had the best conditions to bargain with the superpower in loyal terms (E Silva, 1967, pp. 50-51). ${ }^{15}$

In the process of reaching a powerful international status for its country, the Brazilian military elite had no intention of watching the country become the American «backyard.» Nonetheless, for practical reasons, as pointed out by David Schwam-Baird (1997), it advocated for a close alliance with the United States so that the nation could receive technological assistance in order to accomplish grandeza. Furthermore, Burges (2009) argues that in the late 60 s «the logic behind a dependence on US economic and military aid was becoming increasingly questionable.» (p. 24).

15 The Portuguese original version is: «[...] quando entre nossos vizinhos hispano-americanos recrudesce indisfraçável uma oposição aos Estados Unidos da América [...], o Brasil pode estar em condições superiores [...] para uma barganha leal» (E Silva, 1967, pp. 50-51). 
Intelligence was to have crucial relevance for the security apparatus that the Brazilian military developed under the authoritarian regime. SNI had the legal right to have offices placed in each governmental ministry, university and state-owned enterprise, in order to inspect daily activities. Along with the central SNI agency, regional branches were established in the main Brazilian cities (Stepan, 1988; Antunes, 2002).

The SNI was meant to coordinate the three intelligence services of the Army, Air Force and Navy, but in practice, the Army kept its autonomy and dominated the other two services, maintaining close ties with the SNI. Nonetheless, the SNI had the monopoly on advanced intelligence training. In 1971 a school for intelligence education and training, the ESNI, was created. This school was answerable directly to the president. It fact, it was the highly sophisticated professionalization of intelligence, under the supervision of the military, what led Brazilian intelligence agencies to play a key role in the national security apparatus (Stepan, 1988, Cepik \& Antunes, 2004).

As Brazilian military gave intelligence services a key role to play in Brazil's bid for regional influence, this may explain why the decision makers were interested in participating in the Plan Condor; an arrangement for interchanging intelligence in order to combat Communism in Latin America. ${ }^{16}$ According to a partially declassified CIA document, «Operation Condor is a cooperative arrangement among security services of Chile, Argentina, Bolivia, Paraguay, Uruguay, and Brazil to counter terrorism and subversion» (CIA, 1977, April 8).

Brazil was not one of the first countries to join the Plan Condor, it joined only after the plan had already been agreed upon by Chile and Argentina, which were the most important members at the time. Notwithstanding, Brazilian power holders soon showed their intention to intervene by all means necessary in the internal conflicts of its neighbors to contend subversion.

Brazil was invited by the Chilean director of the Dirección de Inteligencia Nacional (DINA) to participate in the first official meeting of Plan Condor, which had as its main objective examining the «efficient coordination that allows an opportune exchange of information and experiences, in addition

${ }^{16}$ A CIA cable sent in 1976 mentions that «Brazil has adhered to the original agreement among Argentina, Uruguay, Chile, Bolivia, and Paraguay to cooperate to exchange information on terrorism and subversion [...]». (Kraft \& Siekmeier, 2009, CIA cable, August 12. 
that the security heads could know each other, at a certain grade» (CNV, 2014). This meeting took place in Santiago de Chile in 1975. Six countries attended: Argentina, Bolivia, Brazil, Chile, Paraguay and Uruguay. The two Brazilian military officers who attended had experience in combatting the Araguaia guerrilla. ${ }^{17}$

Brazilian intelligence officers were cooperating closely with the activities and operations of other South American intelligence services, and the SNI also participated in the creation of foreign intelligence services, such as the Chilean DINA (MacSherry, 2009). Furthermore, DINA officers were sent to Brazil and South Africa ${ }^{18}$ to receive training (Rivas Nieto, 2008).

It is important to note that in the 1970s and in the 1980s the power of SNI had expanded to such a degree that two presidents of the military regime, Médici and Figueiredo, had been heads of this organization. Although in most cases the SNI was not directly involved in operations, its actions like phone bugging and violation of correspondence ultimately led to arrests and torture (MacSherry, 2009). One of the three sections of the agency, Internal Security, was in charge of monitoring individuals deemed to be a threat to the regime (Cepik \& Antunes, 2003). ${ }^{19}$ The SNI was exempted from having to inform

[152 ] the Congress about its organization, operations and personnel. Moreover, the head of the central agency had ministerial rank, therefore having a place in the presidential cabinet.

The degree of professionalism and organization of Brazilian intelligence was highly appreciated by the authoritarian regimes of the Southern Cone, such as Uruguay. The hard-line faction of the Uruguayan army was known as the «Brasilianists» (Mares, 2008, p. 394). This certainly enhanced the influence of Brazil among its Latin American neighbors, namely in political and ideological aspects. Consequently, by way of its intelligence apparatus, Brazil could intervene indirectly in these countries, making it a regional power. The US intelligence estimated: «lt is unlikely that Brazil will intervene openly in its neighbor's internal affairs, but the regime will not be above using the threat of intervention or tools of diplomacy and covert action to oppose leftist regimes, to keep friendly governments in office.» (Kraft \& Siekmeier, 2009, Doc. 146).

\footnotetext{
${ }^{17}$ The Araguaia guerrilla fought against the military regime between 1967 and 1974.

${ }^{18}$ During the 70 s and the 80 s the South African regime saw the fight against leftist movements as a blunt need.

${ }^{19}$ The other two sections of the SNI were Strategic Information and Special Operations.
} 
The sophisticated Brazilian intelligence apparatus was therefore used during the military regime not only for the purposes of combating internal subversion foci, but also to fight left-wing revolutionary activities in other South American nations within the framework of the Brazilian national security doctrine. Thus, while it is common to argue that Brazil's foreign policy was entirely subservient to US interests, this doctrine had facets that sought to assert an autonomous Brazilian influence in the region.

\section{The Abertura}

From the mid-1970s onwards, the rising criticism against the Brazilian military regime was isolating the country on the international stage (Green, n.d.). This would certainly have negative implications for Brazil's ambitions of becoming a world power. Moreover, the attacks of Brazilian exiles and the Church were contributing to a negative image of the country. For example, the Belgian theologian José Comblin was quite successful criticizing the Brazilian regime. Expelled from Brazil in 1972, his books in English, Portuguese, Spanish and French had an important impact on the scholar world of the 1970s and the 1980s. Carlos Fico notes that between mid-1972 and mid-1983 the SNI received 2,800 letters from European citizens who were concerned over human rights violations (Fico, n.d., p. 23). Even the United States ended the support for the Brazilian government in light of its repression against political dissidents. ${ }^{20}$ As Brian Loveman (1999) observes, Latin American armed forces prepared the elected civilian governments because, among others factors, «they hoped to shed their image as international pariahs» (p. 213).

To accomplish Grandeza, the Geisel government (1974-1979) had significant plans for a trans-Amazonian highway that would link eastern Brazil with Peru, and another highway network that would connect Brazil with Bolivia, Peru, Colombia, and other countries. As Wayne Selcher (1977, p. 19) has claimed, «Brazil could thus influence the course of development in the Amazonian regions of neighboring states via cross-border economic attraction.» The army was to have an important task building infrastructures across the Amazon.

\footnotetext{
${ }^{20}$ In 1977 the US Embassy in Uruguay gave a temporary visa to Leonel Brizola, who was exiled in this country in order to save him from being delivered to Brazil by the Uruguayan authorities. Brizola remained a few months in the United States before leaving to Portugal (MacSherry, 2009). In April 1974, the Portuguese Carnation revolution allowed the return of democracy to the country. Therefore, Brazilian dissidents and opponents to the military regime were welcomed in the Portugal of the mid-1970s.
} 
By the late 1980s, in an internal context of democratization and the end of Cold War, Brazilian intelligence began to focus its attention more on external issues. In an interview with the Folha de São Paulo, President Sarney (1985-1990) requested the SNI international affairs reports to be sent to him given their high quality (Valente, 2010, 31 de maio). Still, the SNI continued to monitor workers' strikes and the activities of leftist electoral candidates as part of the internal security program (Antunes, 2002, p. 92). Golbery do Couto e Silva, the father of SNI, died in 1987, leaving a life's work that is still seen with great controversy. Under President Sarney, civil and military intelligence services began to be restructured. A newly approved SNI handbook redefined the Brazilian doctrinal intelligence concepts. By the end of Sarney's term, a workgroup was created in order to propose a «new SNI.» This included redefining its objectives and organization. After 1985, the process of consolidation of Brazilian democracy and the end of the Cold War led to a shift from the combat against «internal enemies» toward other intelligence priorities marked by the events of a new world order. In the 1990s, Brazilian military saw deterring threats to the national sovereignty and integrity as its main priority, such as a presumed foreign interference in the Amazon. On the other hand, President Collor de Mello charged the national intelligence service with the formulation and implementation of a national system to control illegal activities in the Amazon, fearing that international criticism regarding the ecological problems affecting this territory might justify a foreign intervention. Nonetheless, Collor provoked confrontation with the military when he decided to approve a Yanomami indigenous reserve on the border with Venezuela, which was viewed by the Brazilian military as a buffer zone crucial to national security (Zirker \& Filho, 2000).

\section{The Agência Brasileira de Inteligência (ABIN): «New» Security Concepts}

At the beginning of the 1990s, Brazilian leaders started to develop a security doctrine emphasizing on the implications the new world order would have for national security and sovereignty. The new security priorities were related, inter alia, to the Brazil's objective of defending itself from the perceived threat of interference on the part of the developed countries (e.g. the United States) in territories with rich resources, and in achieving the status of a great power. Since the mid-1990s Brazilian intelligence, still deeply influenced by the military doctrine, had reconstructed its machinery and reformulated its priorities in order to tackle perceived threats related to a novel core of issues 
defined by a new national security doctrine. Nonetheless, the aspirations of greatness prevailed and were to be assisted by the new Brazilian Intelligence Agency, the Agência Brasileira de Inteligência (ABIN, n.d. a). ${ }^{21}$

President Collor (1990-1992) took the first steps to abolish the SNI and replace it with a new intelligence agency, which should be less dependent on military tutelage and under democratic control. Meanwhile, a new legal framework was developed in order to deter intelligence services from exceeding the scope of their powers. In 1999, a federal law finally established officially the ABIN, the new Brazilian Intelligence Agency, as the central organ of the Brazilian intelligence system (SISBIN).

Cepik (2017) observes that the law that created the SISBIN gave the President the highest level of authority over the system. Since 2002, a further step was accomplished to enhance the control over ABIN activities, putting it under the supervision of the Institutional Security Cabinet (GSI in Portuguese). Nonetheless, Jorge Zaverucha (2008) cautioned against the lack of control over the Agency. For example, in 2000 Federal Deputy José Genoino denounced political espionage pursued by ABIN officers. The deputy stressed: «lf it is parallel power, it is serious. If it is not, it is even more serious» (p. 187). Furthermore, Zaverucha (2008) argues that in terms of power «there is a militarization of $\mathrm{ABIN}$.» For example, «there is a military filter that decides which information collected by ABIN will be sent to the President» (p. 191).

The ABIN is tasked with planning, coordinating and implementing intelligence activities in defense of the country and its sovereignty. This is the strategic objective of the Agency according to the information in its webpage: «Antecipar fatos e situações que possam impactar a segurança da sociedade e do Estado brasileiros, de modo a assessorar o mais alto nivel decisorio do pais [...].» (ABIN, n.d. b).

One of the main purposes Collor de Mello had by extinguishing the SNI in 1990 was the dismantlement of the military control over this intelligence agency, which caused, in the words of Daniel Zirker \& João Filho (2000, p. 110), a «military identity crisis.» Nonetheless, his successors Itamar Franco and Fernando Cardoso, worked more closely with the military regarding security

${ }^{21}$ Collor de Mello tried to replace the SNI by the Secretaria de Assuntos Estratégicos (1990-1994), but this attempt was short-lived. 
and intelligence issues. At the end of the 1990s the military was successful in maintaining control over key intelligence agencies (Zirker \& Filho, 2000, p. 148). It is worth noting that ABIN made serious efforts to provide its analysts with a higher standard of professional education. In fact, there is a significant participation of university professors in the ABIN School and the agency has signed a cooperation agreement with the University of Brasilia in order to provide distance-education to the whole Brazilian territory (Cepik \& Antunes, 2004, p. 150).

The end of the Cold War led Brazilian intelligence to rethink its priorities, but internal security continued to be a concern of intelligence agencies (Cepik \& Antunes, 2003, p. 351). For example, the Landless Workers' Movement remained closely monitored (Antunes, 2002, p. 108). Nonetheless, the new international order led Brazilian intelligence to devote more attention to the clash between its interests and those of the developed countries, particularly the United States. A new security doctrine was developed by the military, according to which the West-East conflict was replaced by North-South divergences. Zirker \& Filho (2000) note that the «insistence upon the threats and risks imposed upon Brazilian sovereignty by the asymmetry in NorthSouth relations became a common concern in military analyses after 1991.» [156] (p. 113).

Among the «hot issues» that arose were serious concerns on the part of the Brazilian army regarding the US aspirations toward Brazil's territory and its sovereignty in the Amazon. According to scholar Adriana Marques (2004, p. 10), Brazilian armed forces had the perception that the United States wanted to take advantage of the strategic vulnerability of the Brazilian Amazon. In fact, US leaders had advocated that «general interests of humanity» would justify an intervention in the Amazon, with or without the approval of the UN. There was a deep divergence of points of view between Brazil and the United States regarding issues such as Amazonian ecological matters and the construction of infrastructure throughout the Amazon. Brazilian leaders also had concerns about the intentions of other developed countries.

Mitterrand, the French President, stated in an open declaration that Brazil should give away «parts of its sovereignty» in the Amazon, because it would be the only way to help to protect it as a «patrimony of humanity» (Marques, 2004, p. 9). The Brazilian army has concentrated its efforts on the elaboration of a «genuine Brazilian military doctrine» based on the notion that 
the enemies of the army are located in the Northern Hemisphere (Marques, 2004, p. 14).

In 1998, President Fernando Cardoso expressed openly his concerns over a speech given by General Patrick Hughes, director of the US Defense Intelligence Agency, considering a US intervention in the Brazilian Amazon, should Brazil put «the environment of the United States at risk» (Zirker \& Filho, 2000, p. 115). Moreover, Brazilian public opinion had expressed concerns over Plan Colombia, because it was afraid the United States would use Colombian territory to interfere in the Brazilian Amazon (Moreano, 2005).

In 2002 the Center of Operations and Management of the Amazonian Protection System (CENSIPAM) was created. According to Marco Cepik \& Gustavo Möller (2017, p. 11) its focus was on «a critical region for the security and the development of Brazil [...].» It was created in a context of stressful regional relations, since at the beginning of the $21^{\text {st }}$ century the Plan Colombia - an agreement between Colombia and the United Nations with the purpose of fighting drug trafficking - raised concerns on the part of Brazil.

Plan COBRA, a counter-guerrilla operation conceived as a cooperation between Colombia and Brazil, was to be implemented along the ColomboBrazilian border. Working on Plan COBRA from Brazil's side was the Brazilian military, federal police and the intelligence agency, ABIN. Few years later, the Amazon Surveillance System (SIVAM) began its operations as part of the Amazonian Protection System (SIPAM). Among its objectives are border control, environment protection and monitoring of illegal activities. Furthermore, Nascimento (2010) states that from the point of view of the Brazilian defense policy new perspectives on freshwater and biodiversity became crucial.

Zirker describes SIVAM as «The most important Brazilian military project in the post-Cold War.» (Zirker \& Filho, 2000, p. 18). Nowadays, while the technical aspects of SIVAM/SIPAM are under the direction of the Air Force, $\mathrm{ABIN}$ is in charge of the protection and security of the information collected by this system.

Adriana Marques (2004) notes that Brazil tried to persuade its neighboring countries to cooperate with SIVAM in the framework of a regional defense and security strategy. Therefore, it can be said that intelligence cooperation 
with South American nations, so well viewed by the Brazilian military under the authoritarian rule, propitiated a Brazilian regional cooperation security strategy that highlighted the fight against transnational threats, such as narcotrafficking, organized crime, ecological disasters and guerrilla activities. Nonetheless, under Collor de Mello and Cardoso the idea behind this security strategy was still led by the Brazilian aspirations to achieve hegemony in Latin America, replacing the influence of the United States.

\section{Conclusion}

The sophisticated Brazilian intelligence apparatus was used during the military regime not only to combat internal subversion foci, but also to monitor and to fight left-wing revolutionary activities in other South American nations within the framework of the Brazilian national security doctrine. While it is common to argue that Brazil was entirely subservient to US interests and imported US security concepts, in fact Brazilian doctrine had facets that sought to assert an autonomous influence of the country in the region.

Since 1964, Brazilian military sought to enhance the autonomous project regarding «Brasil potencia». Rather than subserviently helping US

[158] foreign policy goals against Communism, the Brazilian state was to remove subversion foci according to national interests. Chaos derived from «red» subversion was considered to be a major obstacle to attain Grandeza. Using intelligence as a tool, the Brazilian security strategy had to take into consideration aspects of both internal and regional security, while cooperating jointly with underdeveloped nations and centers of power in the Western world, in order to consolidate its position in global affairs.

In the post-Cold War era, under Collor de Melo and Fernando Henrique Cardoso, Brazilian intelligence was still seen as a crucial tool of state power to achieve regional hegemony. With the creation in 1999 of the new national intelligence agency, ABIN, emphasis was put on the professionalization of intelligence analysis. Under Collor and Cardoso Brazil was determined to protect its territorial integrity and sovereignty against the presumed aspirations of developed countries, while «new» rivals were conceptualized. Furthermore, more than ever, technology and intelligence had the scope to allow the country to achieve an old dream, regional hegemony. 


\section{References}

1. Agência Brasileira de Inteligência (ABIN). (n.d. a). Seguridad de las Fronteras. Retrieved from http://www.abin.gov.br/es/atuacao/areas-prioritarias/seguranca-dasfronteiras/

2. Agência Brasileira de Inteligência (ABIN). (n.d. b). Missão, Visão e Valores. Retrieved from http://www.abin.gov.br/es/institucional/missao-e-visao/

3. Antunes, Priscilla. (2002). SNI \& ABIN. Uma Leitura da Atuação dos Serviços Secretos Brasileiros ao Longo do Século xx. Rio de Janeiro: FGV.

4. Burges, Sean. (2009). Brazilian Foreign Policy After the Cold War. Gainesville: University Press of Florida. https://doi.org/10.5744/florida/9780813033334.001.0001

5. Cardona, Diego. (2004). L'Evolution de la Notion de Sécurité au Méxique, $(\mathrm{PhD}$ thesis), Université de Genève, Genève.

6. Central Intelligence Agency (CIA). (1977, April 8). Documents on Operation Condor. Retrieved from https://www.cia.gov/library/readingroom/docs/ DOC_0000345186.pdf

7. Cepik, Marco. (2002). Inteligência e políticas públicas: dinâmicas operacionais e condições de legitimação. Security and Defense Studies Review, 2 (2), pp. 246-267.

8. Cepik, Marco. (2007). Structural Change and Democratic Control of Intelligence in Brazil. In: Bruneau, Thomas (ed.). Reforming Intelligence (pp. 149-169). Austin: University of Texas.

9. Cepik, Marco \& Antunes, Priscilla. (2003). Brazil's New Intelligence System: An Institutional Assessment. International Journal of Intelligence and Counterintelligence, 16, pp. 349-373. https://doi.org/10.1080/713830446

10. Cepik, Marco \& Antunes, Priscilla. (2004). Professionalization of Intelligence Activity in Brazil. In: Swenson, Russell et al. (eds.). Intelligence Professionalism in the Americas (pp. 133-154). Washington D. C.: Center for Strategic Intelligence Research.

11. Cepik, Marco \& Möller, Gustavo. (2017). National Intelligence Systems as Networks: Power Distribution and Organization Risk in Brazil, Russia, India, China, and South Africa. Brazilian Political Science Review, 11 (1), pp. 1-26. https://doi. org/10.1590/1981-3821201700010001

12. Child, Jack. (1979). Geopolitical Thinking in Latin America. Latin American Research Review, 14 (2), pp. 89-111.

13. Comblin, Joseph. (1979). The Church and the National Security State. New York: Orbis.

14. Comissão Nacional da Verdade (CNV). (2014). Relatório Volume ı. Brasília: CNV.

15. E Silva, Golbery do Couto. (1967). Geopolítica do Brasil. Rio de Janeiro: José Olympio.

16. Fico, Carlos. (n.d.). The Dictatorship shows its Cards: Images and Memories of the 1964-1985 Period. Working Paper, University of Toronto. 
17. Flemes, Daniel. (2010). Brazil: Strategic Options in the Changing World Order. In: Flemes, Daniel (ed.). Regional Leadership in the Global System. Ideas, Interests and Strategies of Regional Powers (pp. 93-112). Farnham: Ashgate.

18. Fox, Carlston. (2001). The US Army School of the Americas and US National Interests in the $20^{\text {th }}$ Century. (Master Thesis). Virginia Tech, Virginia.

19. Gaspari, Elio. (2014). A ditadura encurralada. Rio de Janeiro: Intrínsica.

20. Green, James. (n.d.). Restless Youth. Working Paper, Brown University.

21. Guevara, Gisela da Silva. (2014, 4-7 de agosto). El putsch de 1964, Servicios de inteligencia e ideas hegemónicas en Sudamérica. Ix Encontro Brazilian Asociation of Political Science, Brasilia.

22. Guevara, Gisela da Silva (ed.). (2018). Brasil y sus vecinos, estrategias de smart power (2003-2014). Bogotá, D. C.: Universidad Externado de Colombia.

23. Guevara, Gisela da Silva \& Ardila, Martha. (2018). Un conocimiento situado en perspectiva comparada. El concepto de autonomía en México y Brasil. In: FrassonQuenoz, Florent et al. Teorías sobre relaciones internacionales. Perspectivas y lecturas desde América Latina (pp. 217-264). Bogotá, D. C.: Universidad Externado de Colombia.

24. Headquarters. Department of the Army. (2010). Intelligence. Federation of American Scientist. Retrieved from http://www.fas.org/irp/doddir/army/fm2-0.pdf

Herman, Michael. (2003). Intelligence, Power in Peace and War. Cambridge: Cambridge University.

[160] 25. Hurrell, Andrew. (2010). Regional Powers and the Global System from a Historical Perspective. In: Flemes, Daniel (ed.). Regional Leadership in the Global System. Ideas, Interests and Strategies of Regional Powers (pp. 15-28). Farnham: Ashgate.

26. Kraft, Douglas \& Siekmeier, James (eds.). (2009). Foreign Relations of the United States, 1969-1976, Volume E-10, Documents on American Republics, 19691972. Brazil. Foreign Relations of the United States. Retrieved from https://history. state.gov/historicaldocuments/frus1969-76ve10/ch4

27. Loveman, Brian. (1999). For la Patria. Politics and the Armed Forces in Latin America. Delaware: Scholarly Resources.

28. MacCann, Frank. (1995). Brazil and World War II: The Forgotten Ally. Estudios Interdisciplinarios de América Latina y el Caribe, 6 (2). Retrieved from http://eial.tau. ac.il/index.php/eial/article/view/1193/1221

29. MacSherry, Patrice. (2009). Los estados depredadores: la Operación Cóndor y la guerra encubierta en América Latina. Santiago de Chile: LOM.

30. Mares, David. (2008). The National Security State. In: Holloway, Thomas (ed.). A Companion to Latin American History (pp. 386-405). Oxford: Blackwell. https://doi.org/10.1111/b.9781405131612.2008.00023.x

31. Marques, Adriana. (2004). A estratégia amazônica do exército brasileiro. GIGA's Working Paper, Hamburgo. 
32. Moreano Urigüen, Hernán. (2005). Colombia y sus vecinos frente al conflicto armado. Quito: Flacso.

33. Nabers, Dirk. (2010). Power, Leadership and Hegemony in International Politics. In: Flemes, Daniel (ed.). Regional Leadership in the Global System. Ideas, Interests and Strategies of Regional Powers (pp. 51-70). Farnham:Ashgate.

34. Nascimento, Durbens. (2010). Amazônia e defesa. Belem: UFPA.

35. National Intelligence Council (NIC). (2004). Mapping the Global Future. Office of the Director of National Intelligence. Retrieved from https://www.dni.gov/ files/documents/Global\%20Trends_Mapping\%20the \%20Global \%20Future $\% 20$ $2020 \%$ 20Project.pdf

36. Nel, Philip \& Stephen, Matthew. (2010). The Foreign Economic Policies of Regional Powers in the Developing World. In: Flemes, Daniel (ed.). Regional Leadership in the Global System. Ideas, Interests and Strategies of Regional Powers (pp. 71-92). Farnham: Ashgate.

37. Nye, Joseph. (2004). Soft Power. The Means to Success in World Politics. New York: Public Affairs.

38. Rivas Nieto, Pedro. (2008). Doctrina de seguridad nacional y regímenes militares en Iberoamerica. Alicante: ECU.

39. Rose, R. S. (2005). The Unpast: Elite Violence and Social Control in Brazil 1954-2000. Athens: Ohio University.

40. Rouquié, Alain. (2007). Le Brésil au XXI Siécle. Naissance d'un Nouveau Grand. Paris: Fayard.

41. Schwam-Baird, David. (1997). Ideas and Armaments. Military Ideologies in the Making of Brazil's arms industries. Boston: The University Press of America.

42. Selcher, Wayne. (1977). The National Security Doctrine and Policies of the Brazilian Government. Defense Technical Information Center. Retrieved from https:// apps.dtic.mil/dtic/tr/fulltext/u2/a047581.pdf

43. Spektor, Matias. (2010). Brazil: The underlying Ideas of Regional policies. In: Flemes, Daniel (ed.). Regional Leadership in the Global System. Ideas, Interests and Strategies of Regional Powers (pp. 191-205). Farnham: Ashgate.

44. Stepan, Alfred. (1988). Rethinking Military Politics: Brazil and the Southern Cone. New York: Princeton University.

45. Valente, Rubens. (2010, 31 de maio), Governo Sarney espionou críticos mesmo após fim da ditadura. Folha de São Paulo. Retrieved from https://www1.folha. uol.com.br/fsp/poder/po3105201002.htm

46. Vigevani, Tullo \& Cepaluni, Gabriel .(2009). Brazilian Foreign Policy In Changing Times: The Quest For Autonomy From Sarney to Lula. Boulder: Lexington Books.

47. Weyland, Kurt. (2016). Realism Under Hegemony: Theorizing the Rise of Brazil. Journal of Politics in Latin America, 8 (2), pp. 143-173. https://doi. org/10.1177/1866802X1600800205 


\section{Gisela da Silva Guevara}

48. Zaverucha, Jorge. (2008). A militarização da Agência Brasileira de Inteligência. Revista de Sociologia e Política, 16 (31), pp. 177-195. https://doi.org/10.1590/S010444782008000200013

49. Zirker, Daniel \& Filho, João. (2000). Nationalism, National Security and Amazônia. Armed Forces and Society, 27 (1), pp. 105-129. https://doi. org/10.1177/0095327X0002700107 